\title{
Animal model of chronic abdominal hernia in rabbit ${ }^{1}$
}

\author{
Modelo animal de hérnia abdominal crônica em coelhos
}

\author{
Walter da Silva ${ }^{I}$, Djalma José FagundesiI, Amélia Cristina Seidel ${ }^{I I I}$, Murched Omar Taha ${ }^{\mathrm{IV}}$

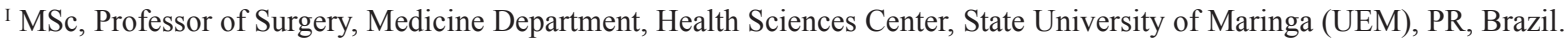 \\ ${ }^{\text {II }} \mathrm{PhD}$, Associate Professor, Operative Technique and Experimental Surgery Division, Surgery Department, UNIFESP, Sao Paulo, Brazil. \\ III PhD, Professor of Vascular Surgery, Medicine Department, Health Sciences Center, UEM, PR, Brazil. \\ Iv PhD, Affiliate Professor, Operative Technique and Experimental Surgery Division, Surgery Department, UNIFESP, Sao Paulo, Brazil.
}

\begin{abstract}
Purpose: To create a feasible animal model of hernia that should be reliable to test the different types of mesh and/or surgical technique. Methods: Thirty six male New Zealand albino rabbits were submitted to surgical procedure to provoke a standard hole in the abdominal wall. A metallic frame measuring $3 \mathrm{~cm}$ length and $1 \mathrm{~cm}$ width was allocated longitudinally on the umbilicus scar and the comprehensive three squared centimeters area was resected. A continuous 4.0 polyamide was performed to closure the subcutaneous and skin. Results: During three weeks a score of signals/symptoms was performed to evaluate the wound and clinical conditions. No death or severe complications occurred. In the $3 \mathrm{rd}$ week the hernia ring and visceral adhesions were evaluated. Soft omental adherences were present in the hernial sac in all animals. The area of hernia ring ranged from $32.1 \pm 5.5$ to $35.6 \pm 3.1$ squared centimeter and the maximum was $39 \mathrm{~cm}^{2}$ and the minimum was $30 \mathrm{~cm}^{2}$. The model results in protrusion which was similar to a human incisional hernia with hernia sac, visceral adhesions and fibrous healing ring. Conclusion: The model was more reliable to test further techniques or mesh on hernia repair.
\end{abstract}

Key words: Hernia, Ventral. Hernia, Abdominal. Wound Healing. Animal Experimentation. Rabbits.

\section{RESUMO}

Objetivo: Criação de um modelo animal de hérnia que seja confiável para testar as diferentes técnicas e tipos de telas. Métodos: Trinta e seis coelhos foram submetidos a procedimento operatório que provocou uma falha na parede abdominal. Uma moldura metálica com $3 \mathrm{~cm}$ de comprimento e $1 \mathrm{~cm}$ de largura foi colocada longitudinalmente sobre a cicatriz umbilical e ressecada uma área de $3 \mathrm{~cm}^{2}$. Uma sutura contínua de poliamida 4.0 fechou a tela subcutânea e pele. Resultados: durante três semanas o escore de sinais e sintomas foi coletado para avaliar as condições clínicas e da ferida operatória. Não ocorreram óbitos ou complicações graves. Na terceira semana o anel herniário e aderências peritoneais foram avaliadas. Aderências frouxas estavam presentes no saco herniário em todos os animais. A área do anel herniário variou de $32.1 \pm 5.5$ a $35.6 \pm 3.1 \mathrm{~cm}^{2}$, com um máximo de $39 \mathrm{~cm}^{2}$ e um mínimo de $30 \mathrm{~cm}^{2}$. O modelo resultou numa protrusão de vísceras semelhante ao que ocorre em hérnia incisional de humanos. Conclusão: O modelo é factível para testar técnicas operatórias ou telas na reconstrução de hérnias incisionais.

Descritores: Hérnia Ventral. Hérnia Abdominal. Cicatrização de Feridas. Experimentação Animal. Coelhos.

${ }^{1}$ Research performed at Surgery and Experimentation Post-Graduate Program, Operative Technique and Experimental Surgery Division, Surgery Department, Federal University of Sao Paulo (UNIFESP), Brazil.

\section{Introduction}

Incisional and inguinal hernia repair literature is confounded by diverse patient and surgeon specific variables, including surgical technique and type of mesh ${ }^{1,2}$. Nowadays, the laparoscopic access was introduced and plays important role in the success outcome $e^{3,4}$. Thus, the systematic review on hernia repair is a hard task ${ }^{5}$. The consensus or a reliable algorithm to hernia treatment remains a challenge ${ }^{1-5}$.

In the same way, the reports using animals have limiting points like the use of different species, mainly rats ${ }^{6-8}$, rabbits $^{9-11}$ and pigs $^{12-14}$, and different procedures to promote the model of hernia to be used for the further technique and/or mesh reinforce. Most of them make an acute defect by provoking a hole on the abdominal wall, which is immediately repaired. The size of the defect showed a relationship between the degree of protrusion and the intraabdominal pressure. An in vitro study in pigs showed that the protrusion increased at the same air pressure as the defect size increases and protrusion increased with increasing air pressure as also with an increasing defect diameter ${ }^{15}$.

Nevertheless, these acute defects do not represent the current state found in the chronicle hernias. The fibrous tissue involving the hernial ring, the peritoneal adhesions and the hernial sac were not present ${ }^{16,17}$. The abdominal viscera accommodation and abdominal pressure were also different ${ }^{18}$. These elements will be relevant on the evaluation of one technique or mesh. It is well 
known that formation of recurrent inguinal and incisional hernia shows an underlying defect in the wound healing process. Even following mesh repair, an altered collagen formation and insufficient mesh integration has been found as main reason for recurrences ${ }^{19}$.

On account of the pathophysiology of a ventral hernia and the need of standard procedures for hernia treatment, the authors proposing to create a feasible animal model of hernia that should be reliable to test the different types of mesh and/or technique. Thus, the purpose is to investigate to what extent a full-thickness defect in the abdominal wall of rabbits can be enabling, along the weeks, to lead to a stable chronicle ventral hernia.

\section{Methods}

Thirty six male New Zealand albino rabbits, six months old, weighing range from $1,800 \mathrm{~g}$ to $2,200 \mathrm{~g}(1,980 \pm 230)$ were kept in the restrict area facilities for rodent under environment control as follows: humidity (45-55\%); 12 hours light/dark cycle; temperature of $21^{\circ} \mathrm{C}$; acoustic isolation for high noise levels and sudden noises; food; water ad libitum. The care and attention were provided by the animal care staff (Veterinarian and animal technicians).

The experimental protocol was approved by the Ethics Committee of the Federal University of Sao Paulo (UNIFESP). The rabbits were maintained in accordance with the standards of the Guide for the Care and Use of Laboratory Animals (Institute for Laboratory Animal Research, USA, 1996) and to the ethical principles of the Brazilian Committee on Animal Experimentation (COBEA).

Initially a brief review of five years on electronic database of biomedical literature (Medline and Pubmed) was performed in order to identify other animal model of chronicle hernia. Key words from animal species (rats, mice, rabbits, guinea pigs, pigs, mini pigs, dogs, sheep and goats) were used and crossed separately with the key words: mesh, hernia, ventral hernia, incisional hernia, hernia repair, animal model, surgical glue, fibrin glue, abdominal wall healing and systematic review. The pertinent reports were selected to further analysis and to be based upon the proposal model herein.

\section{Anesthesia and analgesia procedure}

The animals were preanesthetized with diazepam $0.5 \mathrm{mg} / \mathrm{kg}$ i.m. and $15 \mathrm{~min}$ later anesthetized with $25 \mathrm{mg} / \mathrm{kg}$ tiletamine/ zolazepan i.m. Fentanyl citrate $0.05 \mathrm{mg} /$ $\mathrm{kg}$ i.m. was used as analgesic. Antibiotic prophylaxis was provided by a single dose of chloramphenicol hemisuccinate $50 \mathrm{mg} / \mathrm{kg}$ i.m. The analgesic nalbuphine hydrochloride was used in a subcutaneous via $(2 \mathrm{mg} / \mathrm{Kg})$ in the first five postoperative days (12/12 hours).

\section{Surgical procedure}

The animals were submitted to surgical procedure to provoke a standard hole in the abdominal wall. Under aseptic conditions a midline scalpel incision was performed about $2.5 \mathrm{~cm}$ above and below the umbilicus scar. The subcutaneous tissue was dissected and identified the linea alba on muscular abdominal wall. A metallic frame measuring $3 \mathrm{~cm}$ in length and $1 \mathrm{~cm}$ in width was allocated longitudinally on the umbilicus scar. The comprehensive 3 squared centimeters area was demarcated and thus resected saving the parietal peritoneum layer. Soft compression of the edges was enough to effective hemostasia. A continuous 4.0 polyamide was performed to close the subcutaneous and skin. An occlusive dressing was set during the first three days.

\section{Three weeks of follow-up}

The signals of wound edema, pain, fever, diet refusal, lack of active movement outside the cage were daily observed and recorded (Chart 1). The edema was measured by a pachymeter in a skin fold in three different points (cranial, middle and caudal) on the wound line. The pain was evaluated by the spontaneous reaction of the animal to the compression of pachymeter beyond the limits of the edema. The sum of scores was recorded as absent ( score $=0$ ), mild (score $=1$ to 5$)$, moderate (score $=6$ to 10 ) or severe ( score $=11$ to 15$)$.

The wound was daily inspected to identify hemorrhagic, serosal or purulent secretions. It also was observed the presence of partial suture dehiscence or evisceration. Once any sign of severe suffering occurred the Veterinarian interrupted the research and the animal was sent to euthanasia.

CHART 1 - Description of the scores values attributed to each one of daily recorded signals and symptoms

\begin{tabular}{|c|c|c|c|}
\hline Recorded Signals/Symptoms & Mild & Moderate & Severe \\
\hline $\begin{array}{l}\text { 1. Edema } \\
\text { (pachymeter skin fold } \\
\text { measure) }\end{array}$ & $0.5-1.0 \mathrm{~cm}$ & $1.1-1.5 \mathrm{~cm}$ & $>1.5 \mathrm{~cm}$ \\
\hline $\begin{array}{l}\text { 2. Pain } \\
\text { (Pachymeter skin compression } \\
\text { and muscular reaction) }\end{array}$ & $1.5 \mathrm{~cm}$ & $1.0 \mathrm{~cm}$ & $0.5 \mathrm{~cm}$ \\
\hline $\begin{array}{c}\text { 3. Fever } \\
\text { (Rectal temperature) }\end{array}$ & $+1^{\circ} \mathrm{C}$ & $+1.5-2^{\circ} \mathrm{C}$ & $>2^{\circ} \mathrm{C}$ \\
\hline $\begin{array}{l}\text { 4. Diet refuse } \\
\text { (Percentage of diet weight) }\end{array}$ & $0-10 \%$ & $11-30 \%$ & $>31 \%$ \\
\hline $\begin{array}{l}\text { 5. Active movement } \\
\text { Outside the cage }\end{array}$ & $\begin{array}{l}100-50 \mathrm{~cm} \\
\text { walk }\end{array}$ & $\begin{array}{l}49-20 \mathrm{~cm} \\
\text { walk }\end{array}$ & $\begin{array}{l}19 \mathrm{~cm} \text { or not } \\
\text { walk }\end{array}$ \\
\hline Range of Score & 1 to 5 & 6 to 10 & 11 to 15 \\
\hline
\end{tabular}




\section{Gross inspection}

After 3 weeks another surgical procedure was performed by a scalpel incision following the line of anterior wound and on the abdominal protrusion (Figure 1). The hernial sac was carefully dissected from skin and subcutaneous tissue and isolated
(Figure 1). The edges of muscular annulus hernia were clearly identified and the hernial sac was opened, cut the eventual adherences and resected (Figure 1). The elliptical area on the abdominal wall was measured (the longitudinal and transversal ratio). Thus, the procedure went on with a four techniques of hernia repair (research in course yet).
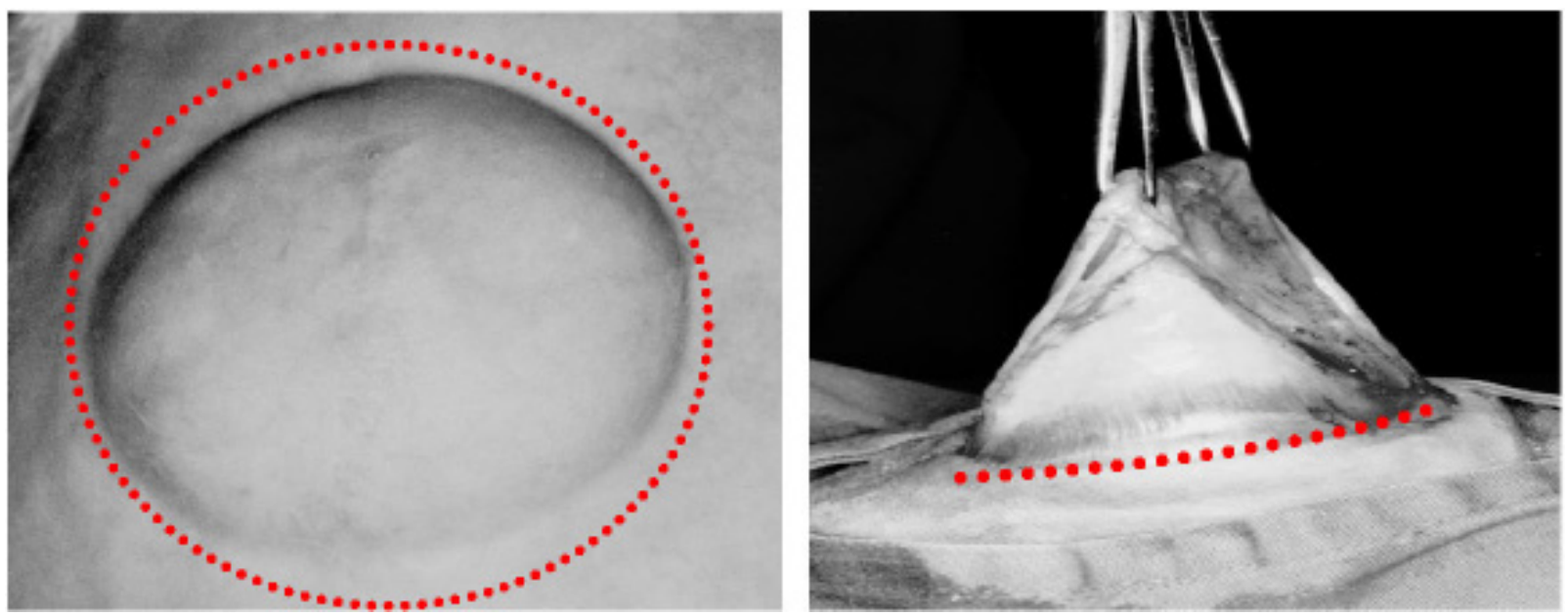

FIGURE 1 - Left: the abdominal protrusion of ventral hernia in the 21 st day of observation. Right: the dissected hernial sac pull up and ready to be resected

\section{Statistical analysis}

The areas $\left(\mathrm{cm}^{2}\right)$ of annulus hernia are expressed as mean $\pm \mathrm{SD}$ (Pearson's chi-square test). The $\mathrm{P}$ value $<0.05$ or $5 \%$ was considered statistically significant.

\section{Results}

The edema, pain and test movement were the main events observed in the first week, but $65 \%$ showed a mild score (Figure 2). No death or evisceration was registered. The partial skin wound dehiscence occurred in three animals $(8.3 \%)$ during the first week, in two animals $(5.5 \%)$ on second week and all of them (100\%) reached the third week without other complications.

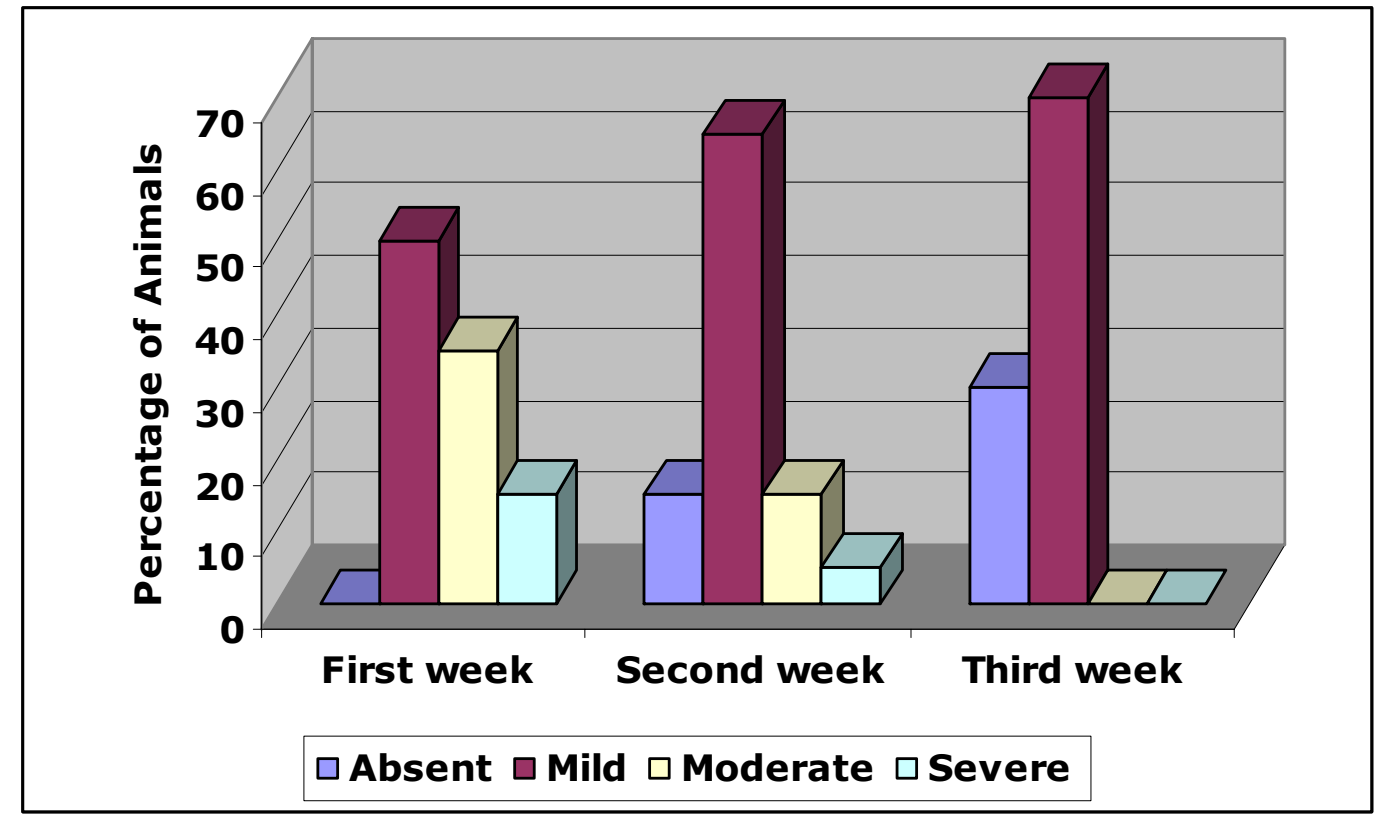

FIGURE 2 - Percentage of animals that concern to the weekly follow-up scores of signals /symptoms 
TABLE 1 - Mean and standard deviation, median, maximum value, minimum value of the area $\left(\mathrm{cm}^{2}\right)$ promoted by the surgical procedure after three weeks

\begin{tabular}{c|cccc} 
& Mean \pm SD & Median & Max. & Min. \\
\hline $\begin{array}{c}\text { Group 1 } \\
(\mathbf{n = 1 0 )}\end{array}$ & $32.1 \pm 5.5$ & 37.5 & 32 & 34 \\
\hline $\begin{array}{c}\text { Group 2 } \\
(\mathbf{n = 1 0 )}\end{array}$ & $35.6 \pm 3.1$ & 34.5 & 33 & 31 \\
\hline $\begin{array}{c}\text { Group 3 } \\
(\mathbf{n = 1 0 )}\end{array}$ & $35,2 \pm 3.8$ & 34,5 & 30 & 30 \\
\hline $\begin{array}{c}\text { Group4 } \\
(\mathbf{n = 6})\end{array}$ & $33.4 \pm 3.4$ & 33.6 & 39 & 32 \\
\hline
\end{tabular}

No significantly statistical differences

The area of defect was randomly distributed in four groups and the results expressed by the mean and standard deviation. No significantly differences in the annulus area were pointed among the animals (Table 1).

The internal annulus was clearly identified as a ring of fibrous tissue that remembers that one of human ventral hernia. Soft adherences of omentum were present in the hernial sac in all animals.

\section{Discussion}

Up to now, the number of studies reporting a standard animal model to improve the knowledge about hernia repair is rather limited. A brief review of five years on electronic data base of biomedical literature (Medline and Pubmed) showed thirty seven reports with rats, nineteen with rabbits, five with pigs or mini pigs, three with guinea-pigs, three with dogs, two with mice and no one with sheep or goats. Except for reports of one research group $^{16,17,20-22}$ in rats and another one in rabbits ${ }^{18}$, almost all studies on wound healing and scar formation, using or not the different types of mesh, are based on the promotion of an acute full-thickness abdominal wall defect that is immediately repaired by a mesh and/or a surgical technique.

The size of the abdominal wall defect reported was variable in the same species. Thus, in rats the defect might be only a middle line incision closed with absorbable suture ${ }^{16,17,20-22}$ or fullthickness defect range of one squared centimeter ${ }^{7}$ up to resections of $1.5 \times 2.5 \mathrm{~cm}^{8,23}, 2 \times 2 \mathrm{~cm}^{24}$ or $2 \times 3 \mathrm{~cm}^{6,25}$. In guinea pigs the size was reported as $3 \times 1 \mathrm{~cm}^{26}$ and in pigs as $10 \times 10 \mathrm{~cm}^{13}, 12 \times 4 \mathrm{~cm}^{12}$ or $5 \mathrm{~cm}$ of diameter ${ }^{14}$. In rabbits the wall defect was referred to sizes of $2 \times 3 \mathrm{~cm}^{27}, 3 \times 3 \mathrm{~cm}^{11,28}, 9 \times 2 \mathrm{~cm}^{18}, 7 \times 3 \mathrm{~cm}^{29}, 5 \times 7 \mathrm{~cm}^{30-32}, 7 \times 5$ $\mathrm{cm}^{9,33-37}$ and $5 \times 8 \mathrm{~cm}^{10}$. Only one study ${ }^{38}$ made reference to the relationship of $2 \times 3 \mathrm{~cm}$ wall resection with the percentage of the defect $(60-70 \%)$ to the total area of the abdominal wall of the mice. The data make clear the lack of a standard procedure, even in the same species, and being so the comparison results have a limiting power of resolution.

We hypothesized that the fibrous tissue around the ring, the tensile forces on the abdominal wall and the hernia sac are crucial to the healing repair, and that they may also play an important role on its recurrence. Thus, at first, this proposition of animal model was designed to achieve two goals: to determine what is the effective muscular resection area enough to promote a stable hernia and how long is the period necessary for this.

In three previous and limited groups of four rabbits different metallic frame sizes were tested. Frame areas smaller than $2 \mathrm{~cm}^{2}$ do not promote a reliable protrusion. The full-thickness defect had a concentric shrinkage due to a healing fibrous tissue around the internal ring involving the muscular and peritoneal layers as well as the subcutaneous. The resulting hernias size was too much variable. Areas larger than $4 \mathrm{~cm}^{2}$ were associated to high rates of partial skin dehiscence and posterior wound infection. A total dehiscence of the suture and eventration also occurred. The area of $3 \mathrm{~cm}^{2}$ showed the most promising model and then chosen for the present study.

The results of present study showed that all animals developed a stable protrusion and the measures of the resulting area from the standard resection showed no significant differences among the four groups (Table 1). At same time, the follow-up showed a progressive decrease on the scores along the three weeks being that in third week the percentage of absent sign was of $35 \%$ and mild was $75 \%$ (Figure 2).

The defect area after three weeks ranged from $32.1 \pm 5.5$ to $35.6 \pm 3.1$ squared centimeters and was similar to other reports that made only the acute full-thickness defect with areas ranging from 35 to 40 squared centimeters ${ }^{9,10,18,30-38}$. The hypothetic advantage of our model was to simulate the surgical findings in the human hernia repair. To make the hernia repair using the model it is necessary the dissection of soft tissue, identification of hernia ring, dissection of hernia sac, removal of the visceral or omental 
adhesions. The mechanical and biological facts involved created more actual conditions similar to those in the surgical practice.

On experimental laparoscopic surgery, animals like rats and rabbits were used only to test the compatibility and inflammatory response of mesh. The studies on techniques were mainly tested in porcine models. The rabbit model described herein can be also feasible to test the laparoscopic access once the dimension of the animal was more suitable than a smaller animal like the rat. On the other hand, the rabbit could replace the porcine with advantage of storage, costs and technical manipulations.

\section{Conclusion}

Our results suggest that full-thickness defect in a rabbit model was feasible and reliable to promote an incisional hernia that could reproduce suitable pathophysiological conditions and could be used as a standard model to improve the evaluation of approaches to hernia repair.

\section{References}

1. Thomas RE, Crutcher R, Lorenzetti D. A systematic review of the methodological quality and outcomes of RCTs to teach medical undergraduates surgical and emergency procedures. Can J Surg. 2007;50:278-90

2. Rodriguez ED, Bluebond-Langner R, Silverman RP, Bochicchio G, Yao A, Manson PN, Scalea T. Abdominal wall reconstruction following severe loss of domain: the R Adams Cowley Shock Trauma Center algorithm. Plast Reconstr Surg. 2007;120:669-80.

3. McCormack K, Wake B, Perez J, Fraser C, Cook J, McIntosh E, Vale L, Grant A. Laparoscopic surgery for inguinal hernia repair: systematic review of effectiveness and economic evaluation. Health Technol Assess. 2005;9:1-203.

4. Bittner R, Sauerland S, Schmedt CG. Comparison of endoscopic techniques vs Shouldice and other open nonmesh techniques for inguinal hernia repair: a meta-analysis of randomized controlled trials. Surg Endosc. 2005;19:605-15.

5. Cheng H, Rupprecht F, Jackson D, Berg T, Seelig MH. Decision analysis model of incisional hernia after open abdominal surgery. Hernia. 2007;11:129-33

6. de Vries Reilingh TS, van Goor H, Koppe MJ, Bodegom ME, Hendriks $\mathrm{T}$, Bleichrodt RP. Interposition of polyglactin mesh does not prevent adhesion formation between viscera and polypropylene mesh. J Surg Res. 2007;140:27-30.

7. Petter-Puchner AH, Fortelny RH, Mittermayr R, Walder N, Ohlinger W, Redl H. Adverse effects of porcine small intestine submucosa implants in experimental ventral hernia repair. Surg Endosc. 2006;20:942-6.

8. Bastos EL, Fagundes DJ, Taha MO, Novo NF, Juliano Y, Simoes MJ, Silvado RA. The role of bovine preserved peritoneum in rats ventral hernia: a histological evaluation. Acta Cir Bras. 2006;21:328-31.

9. Bellón JM, Rodríguez M, García-Honduvilla N, Pascual G, Buján J. Partially absorbable meshes for hernia repair offer advantages over nonabsorbable meshes. Am J Surg. 2007;194:68-74.

10. Judge TW, Parker DM, Dinsmore RC. Abdominal wall hernia repair: a comparison of sepramesh and parietex composite mesh in a rabbit hernia model. J Am Coll Surg. 2007;204:276-81.

11. García-Ureña MA, Vega Ruiz V, Díaz Godoy A, Báez Perea JM, Marín Gómez LM, Carnero Hernández FJ, Velasco García MA. Differences in polypropylene shrinkage depending on mesh position in an experimental study. Am J Surg. 2007;193:538-42.

12. Silverman RP, Li EN, Holton LH, Sawan KT, Goldberg NH. Ventral hernia repair using allogenic acellular dermal matrix in a swine model. Hernia.2004;8:336-42.
13. Zieren J, Proske JM, Neuss H, Paul M, Müller JM. Trevira: a new polyester implant for the treatment of incisional hernia. Results of an experimental study. Ann Chir. 2004;129:343-6.

14. Kramer K, Senninger N, Herbst H, Probst W. Effective prevention of adhesions with hyaluronate. Arch Surg. 2002;137:1313-4.

15. Knook MT, van Rosmalen AC, Yoder BE, Kleinrensink GJ, Snijders CJ, Looman CW, van Steensel CJ. Optimal mesh size for endoscopic inguinal hernia repair: a study in a porcine model. Surg Endosc. 2001;15:1471-7.

16. DuBay DA, Choi W, Urbanchek MG, Wang X, Adamson B, Dennis RG, Kuzon WM, Franz MG. Incisional herniation induces decreased abdominal wall compliance via oblique muscle atrophy and fibrosis. Ann Surg. 2007;245:140-6.

17. DuBay DA, Wang X, Adamson B, Kuzon WM, Dennis RG, Franz MG. Progressive fascial wound failure impairs subsequent abdominal wall repairs: a new animal model of incisional hernia formation. Surgery. 2005; 137:463-71.

18. Carvalho ZM, Fagundes DJ, Rodrigues OR, Shimidht Jr. A Incisional hernia: an experimental model in rabbits. Acta Cir Bras. 2001;16:82-5.

19. Junge K, Rosch R, Anurov M, Titkova S, Ottinger A, Klinge U, Schumpelick V. Modification of collagen formation using supplemented mesh materials. Hernia. 2006;10:492-7.

20. Franz MG. The biology of hernias and the abdominal wall. Hernia. 2006;10:462-71.

21. Dubay DA, Wang X, Kirk S, Adamson B, Robson MC, Franz. Fascial fibroblast kinetic activity is increased during abdominal wall repair compared to dermal fibroblasts. Wound Repair Regen. 2004;12:539-45.

22. Dubay DA, Wang X, Kuhn MA, Robson MC, Franz MG. The prevention of incisional hernia formation using a delayed-release polymer of basic fibroblast growth factor. Ann Surg. 2004;240:179-86.

23. Meyer T, Schwarz K, Ulrichs K, Höcht B. A new biocompatible material (Lyoplant) for the therapy of congenital abdominal wall defects: first experimental results in rats. Pediatr Surg Int. 2006;22:369-74.

24. Kaya M, Baba F, Bolukbas F, Boleken ME, Kanmaz T, Yucesan S. Use of homologous acellular dermal matrix for abdominal wall reconstruction in rats. J Invest Surg. 2006;19:11-7.

25. Demir U, Mihmanli M, Coskun H, Dilege E, Kalyoncu A, Altinli E, Gunduz B, Yilmaz B. Comparison of prosthetic materials in incisional hernia repair. Surg Today. 2005;35:223-7.

26. Butler CE, Prieto VG. Reduction of adhesions with composite AlloDerm/polypropylene mesh implants for abdominal wall reconstruction. Plast Reconstr Surg. 2004;114:464-73.

27. Gangwar AK, Sharma AK, Kumar N, Kumar N, Maiti SK, Gupta OP, Goswami TK, Singh RJ. Acellular dermal graft for repair of abdominal wall defects in rabbits. S Afr Vet Assoc. 2006;77:79-85.

28. Gamba PG, Conconi MT, Lo Piccolo R, Zara G, Spinazzi R, Parnigotto PP. Experimental abdominal wall defect repaired with acellular matrix. Pediatr Surg Int. 2002;18:327-31.

29. Menon NG, Rodriguez ED, Byrnes CK, Girotto JA, Goldberg NH, Silverman RP. Revascularization of human acellular dermis in fullthickness abdominal wall reconstruction in the rabbit model. Ann Plast Surg. 2003;50:523-7.

30. Young RM, Gustafson R, Dinsmore RC. Sepramesh vs. Dualmesh for abdominal wall hernia repairs in a rabbit model. Curr Surg. 2004;61:77-9. 31. Greenawalt KE, Butler TJ, Rowe EA, Finneral AC, Garlick DS, Burns JW. Evaluation of sepramesh biosurgical composite in a rabbit hernia repair model. J Surg Res. 2000;94:92-8.

32. Buján J, Contreras LA, Carrera-San Martín A, Bellón JM. The behavior of different types of polytetrafluoroethylene (PTFE) prostheses in the reparative scarring process of abdominal wall defects. Histol Histopathol. 1997; 12:683-90

33. Bellón JM, Rodríguez M, García-Honduvilla N, Pascual G, Gómez Gil V, Buján J. Peritoneal effects of prosthetic meshes used to repair abdominal wall defects: monitoring adhesions by sequential laparoscopy. J Laparoendosc Adv Surg Tech A. 2007;17:160-6. 
34. Bellón JM, López-Hervás P, Rodríguez M, García-Honduvilla N, Pascual G, Buján J. Midline abdominal wall closure: a new prophylactic mesh concept. J Am Coll Surg. 2006;203:490-7.

35. Bellón JM, Rodríguez M, Serrano N, García-Honduvilla N, Gómez V, Buján J. Polypropylene and polydioxanone show similar biomechanical efficacy in midline closure. Cir Esp. 2005;78:377-81.

36. Bellón JM, Serrano N, Rodríguez M, García-Honduvilla N, Pascual G, Buján J. Composite prostheses for the repair of abdominal wall defects: comparative study of physical and/or chemical barriers. Cir Esp. 2005;77:351-6.

37. Bellón JM, García-Carranza A, Jurado F, García-Honduvilla N, Carrera-San Martín A, Buján J. Evaluation of a new composite prosthesis (PL-PU99) for the repair of abdominal wall defects in terms of behavior at the peritoneal interface. World J Surg. 2002;26:661-6.
38. Drewa T, Galazka P, Prokurat A, Wolski Z, Sir J, Wysocka K, Czajkowski R. Abdominal wall repair using a biodegradable scaffold seeded with cells. J Pediatr Surg. 2005;40:317-32.

\section{Acknowledgement}

The authors would like to thank to Profa. Maria do Carmo Negrini Fagundes for the English language text revision.

Conflict of interest: none Financial source: CAPES

\section{Correspondence:}

Djalma José Fagundes

Rua Camé, 244/33

03121-020 Sao Paulo - SP Brazil

Phone: (55 11)2604-3186

Fax: (55 11)2604-3147

djfagundes.dcir@epm.br

Received: January 20, 2009

Review: March 18, 2009

Accepted: April 15, 2009

\section{How to cite this article}

Silva W, Fagundes DJ, Seidel AC, Taha MO. Animal model of chronic abdominal hernia in rabbit. Acta Cir Bras. [serial on the Internet] 2009 July-Aug;24(4). Available from URL: http://www.scielo.br/acb 